\title{
AKRUAL
}

Jurnal Akuntansi

http://fe.unesa.ac.id/ojs/index.php/akrl

\section{PENGARUH LABA AKUNTANSI, ARUS KAS OPERASI, PRICE TO BOOK VALUE, DAN KINERJA KEUANGAN PERUSAHAAN DENGAN PENDEKATAN ECONOMIC VALUE ADDED TERHADAP RETURN SAHAM (STUDI KASUS PADA SAHAM PERUSAHAAN PERTAMBANGAN DI BURSA EFEK INDONESIA PERIODE TAHUN 2008-2010)}

\author{
Ismail Marzuki \\ Susi Handayani \\ Universitas Negeri Surabaya \\ E-mail: susihandayani_76@yahoo.com \\ Artikel diterima: 16 September 2012 \\ Terakhir direvisi: 10 Oktober 2012
}

\begin{abstract}
The objectives of this research is to examine and analyze the influence of Accounting Profit, Operation Cash Flow, Price to Book Value, and Company Financial Performance Through Economic Value Added Approach to stock return of mining company that listed at Indonesia Stock Exchange in the period of 2008 - 2010. This research was an causal research with quantitative approach. The analyzing technique used in this research is multiple linier regressions analysis with SPSS program version 11.5. The result of this research shows that variable of accounting profit and operation cash flow do not have significant influence to stock return. While, variable of Price to Book Value and Company Financial Performance Through Economic Value Added Approach have a positive and significant influence to stock return of mining company that listed at Indonesia Stock Exchange in the period of 2008 - 2010.
\end{abstract}

Keywords: Accounting Profit, Operation Cash Flow, Price to Book Value, Economic Value Added, Stock Return

\section{PENDAHULUAN}

Investor yang rasional tentunya akan mempertimbangkan dua hal sebelum memutuskan untuk membeli saham, yaitu pendapatan yang diharapkan dan risiko yang terkandung dalam alternatif investasi tersebut. Untuk dapat memperhatikan kedua hal tersebut, perlu dilakukan penilaian baik itu dengan menggunakan teknik analisis fundamental atau menggunakan teknik analisis teknikal. Dalam melakukan analisis fundamental ini sendiri, sangat dibutuhkan informasi yang bersifat fundamental, seperti data laporan keuangan.

Di dalam informasi laporan keuangan akan disajikan informasi penting mengenai kinerja keuangan perusahaan yang sering digunakan oleh investor sebagai determinan utama dalam pengambilan keputusan investasi di pasar modal. 
Untuk dapat mengukur kinerja keuangan suatu perusahaan diperlukan seperangkat metode pengukuran kinerja keuangan perusahaan yang terdiri dari berbagai macam metode pengukuran. Beberapa macam metode pengukuran kinerja keuangan yang banyak digunakan oleh para analis untuk mengukur kinerja suatu perusahaan, antara lain adalah Earnings Measures yang mendasarkan kinerja pada accounting profit, Cash Flow Measures, yang mendasarkan kinerja pada arus kas operasi (operating cash flow), dan Value Measures, yang mendasarkan kinerja pada nilai (value based management), termasuk dalam kategori ini adalah metode kinerja keuangan perusahaan dengan menggunakan pendekatan EVA.

Disamping, beberapa metode pengukuran kinerja keuangan perusahaan di atas, terdapat pula metode pengukuran kinerja keuangan dengan menggunakan analisis rasio, terutama dengan menggunakan tolak ukur rasio Price to Book Value (PBV). Penggunaan rasio Price to Book Value (PBV) dalam pengukuran kinerja keuangan perusahaan memiliki peranan yang cukup penting, diantaranya dapat dijadikan sebagai indikator yang sangat sesuai untuk digunakan dalam menilai kinerja perusahaan (Herdiningsih dalam Hidayati, 2010). Hal ini didasari oleh kenyataan bahwa salah satu indikator keberhasilan perusahaan adalah meningkatkan nilai perusahaan, dimana nilai perusahaan tersebut akan digambarkan oleh rasio PBV.

Peranan penting lain yang dimiliki oleh rasio Price to Book Value (PBV) ini diantaranya adalah rasio ini dapat dijadikan sebagai suatu bahan pertimbangan bagi investor untuk memilih saham mana yang akan dibeli dan PBV dapat juga dijadikan indikator harga atau nilai saham (Ahmed dan Nanda dalam Hidayati, 2010). Disamping itu, rasio PBV merupakan rasio yang sangat tepat untuk digunakan dalam menentukan strategi investasi yang dapat diambil investor. Sebab dengan menggunakan rasio PBV, investor dapat melakukan prediksi mengenai saham mana yang akan undervalued dan overvalued, sehingga mereka dapat memperoleh return yang signifikan.

Penelitian yang menghubungkan antara laba akuntansi dengan return saham menunjukkan hasil yang kontradiktif antara satu peneliti dengan penelitian lain. Dimana Sjuchur (2001) dalam penelitiannya menyebutkan bahwa laba akuntansi memiliki pengaruh positif yang signifikan terhadap return saham. Sedangkan, Kusno (2004) dalam penelitiannya menyebutkan bahwa laba akuntansi tidak memiliki pengaruh terhadap return saham.

Penelitian yang menghubungkan antara arus kas operasi dengan return saham menunjukkan hasil yang kontradiktif antara satu peneliti dengan peneliti yang lain. Dimana Pradhono dan Christiawan (2004) dalam penelitiannya menyebutkan bahwa arus kas operasi memiliki pengaruh positif yang signifikan terhadap return saham. Sedangkan, Martani (2009) dalam penelitiannya menyebutkan bahwa arus kas operasi tidak memiliki pengaruh terhadap abnormal return saham.

Penelitian yang menghubungkan antara rasio PBV dengan return saham menunjukkan hasil yang kontradiktif antara satu peneliti dengan peneliti yang lain. Dimana Astuti (2006) dalam penelitiannya menyebutkan bahwa PBV mempunyai pengaruh yang signifikan positif terhadap return saham. Sedangkan, Bramantyo (2006) dalam penelitiannya menyebutkan bahwa tidak ada hubungan yang positif antara PBV terhadap return saham 
Penelitian yang menghubungkan antara EVA dengan return saham menunjukkan hasil yang kontradiktif antara satu peneliti dengan peneliti yang lain. Dimana Christanty (2009) dalam penelitiannya menyebutkan bahwa EVA mempunyai pengaruh positif dan signifikan terhadap return saham. Sedangkan, Pradhono dan Christiawan (2004) dalam penelitiannya menyebutkan bahwa EVA tidak mempunyai pengaruh terhadap return saham.

Berdasarkan riset gap yang telah dikemukakan tersebut, maka dibutuhkan suatu penelitian lanjutan yang sejenis untuk dapat menghasilkan landasan teori dan pola pemikiran yang lebih jelas. Menyikapi kondisi tersebut, maka penelitian ini disusun dengan maksud untuk melakukan analisis secara lebih mendalam dan komprehensif mengenai pengaruh Laba Akuntansi, Arus Kas Operasi, Price To Book Value, dan Kinerja Keuangan Perusahaan dengan Pendekatan Economic Value Added terhadap return saham. Berdasarkan hal tersebut, maka yang menjadi permasalahan dalam penelitian ini adalah: (1) Bagaimanakah pengaruh Laba Akuntansi terhadap return saham perusahaan pertambangan yang terdaftar di BEI sejak tahun 2008-2010? (2) Bagaimanakah pengaruh Arus Kas Operasi terhadap return saham perusahaan pertambangan yang terdaftar di BEI sejak tahun 2008-2010? (3) Bagaimanakah pengaruh Price to Book Value terhadap return saham perusahaan pertambangan yang terdaftar di BEI sejak tahun 20082010? (4) Bagaimanakah pengaruh Kinerja Keuangan Perusahaan dengan Pendekatan Economic Value Added terhadap return saham perusahaan pertambangan yang terdaftar di BEI sejak tahun 2008-2010?

Penelitian ini sendiri bertujuan untuk menganalisis dan menghitung besarnya pengaruh Laba Akuntansi, Arus Kas Operasi, Price To Book Value, dan Kinerja Keuangan Perusahaan dengan Pendekatan Economic Value Added terhadap return saham perusahaan pertambangan yang terdaftar di BEI sejak tahun 2008-2010. Selanjutnya, penelitian ini diharapkan dapat memberikan manfaat berupa kontribusi bagi pengembangan ilmu pengetahuan dalam bidang manajemen keuangan. Hasil penelitian ini juga diharapkan dapat bermanfaat bagi investor bahan pertimbangan dan referensi sebelum mengambil tindakan investasi di pasar modal. Sedangkan, bagi emiten, penelitian ini diharapkan dapat memberi manfaat untuk semakin meningkatkan kinerja perusahaan. Untuk peneliti selanjutnya, penelitian ini diharapkan dapat memberi manfaat sebagai landasan pijak, arahan, dan referensi dalam penelitian selanjutnya.

\section{KAJIAN PUSTAKA}

Menurut Tandelilin (2001:3) investasi merupakan komitmen atas sejumlah dana atau sumber daya lainnya yang dilakukan pada saat ini, dengan tujuan memperoleh sejumlah keuntungan di masa datang. Sedangkan, pasar modal merupakan pasar yang terorganisir dengan baik yang memperdagangkan surat berharga jangka panjang, seperti saham dan obligasi dengan memakai jasa makelar, komisioner, dan underwriter (Anoraga dan Pakarti, 2008:8).

Dalam berinvestasi di pasar modal khususnya dalam instrumen saham, para investor akan berorientasi pada return dan risiko. Return ini sendiri merupakan hasil atau imbalan yang diperoleh dari investasi (Halim, 2005:34). Untuk dapat memaksimalkan return saham tersebut, para investor perlu melakukan penilaian atas saham yang akan dijadikan sebagai alternatif instrumen 
investasinya. Dalam melakukan penilaian, khususnya dengan menggunakan teknik penilaian fundamental, diperlukan informasi mengenai laporan keuangan dari suatu perusahaan.

Laporan keuangan ini sendiri menurut Munawir (2002:31) merupakan suatu alat untuk memperoleh informasi sehubungan dengan posisi keuangan dan hasil-hasil yang telah dicapai oleh perusahaan. Secara garis besar, laporan keuangan ini dapat menghasilkan informasi penting yang sering digunakan oleh para investor sebagai determinan utama dalam pengambilan keputusan investasi di pasar modal. Informasi penting yang dimaksud dalam hal ini adalah informasi mengenai kinerja keuangan perusahaan (Sunardi, 2010).

Untuk dapat melakukan pengukuran secara komprehensif terhadap kinerja keuangan dari suatu perusahaan, maka dapat digunakan beberapa metode pengukuran kinerja keuangan perusahaan. Menurut Helfert (2000) dalam Pradhono dan Christiawan (2004), terdapat tiga alat pengukuran kinerja perusahaan, yaitu Earning Measures, yang mendasarkan kinerja pada accounting profit, Cash Flow Measures, yang mendasarkan kinerja pada arus kas operasi (operating cash flow), dan Value Measures, yang mendasarkan kinerja pada nilai (value based management), termasuk dalam hal ini metode Economic Value Added. Sedangkan menurut Wild, et al. (2005:30), terdapat lima metode pengukuran kinerja keuangan, dimana analisis rasio merupakan analisis keuangan yang paling populer dan paling banyak digunakan di kalangan investor. Dalam penelitian ini, analisis rasio yang akan digunakan hanya direpresentasikan oleh rasio Price to Book Value (PBV).

Laba akuntansi ini sendiri merupakan perbedaan antara revenue yang direalisasi yang timbul dari transaksi pada periode tertentu dihadapkan pada biaya-biaya yang dikeluarkan pada periode tersebut (Harahap, 2007:305). Sedangkan, arus kas operasi IAI (2004) pada PSAK No. 2 merupakan arus kas yang berasal dari aktifitas penghasil utama pendapatan perusahaan.

Rasio Price to Book Value (PBV) merupakan salah satu rasio penilaian pasar yang digunakan untuk mengukur kinerja harga pasar saham terhadap nilai bukunya (Ang dalam Faried, 2008). Sedangkan, metode Economic Value Added (EVA) merupakan ukuran nilai tambah ekonomis yang dihasilkan perusahaan sebagai akibat dari aktivitas atau strategi manajemen (Sunardi, 2010).

\section{Pengaruh Variabel Independen Terhadap Variabel Terikat}

Nilai laba akuntansi yang mengalami peningkatan dapat mencerminkan kemampuan perusahaan dalam menghasilkan laba yang semakin besar pula (Hilal, 2009). Hal ini menunjukkan telah terjadi peningkatan dalam kinerja keuangan perusahaan. Kinerja keuangan perusahaan yang semakin baik ini akan meningkatkan nilai perusahaan di mata para investor (Oktavia, 2008). Hal ini akan mendorong minat dari para investor untuk menanamkan dananya di perusahaan tersebut dengan cara membeli saham dari perusahaan tersebut. Adanya aksi beli ini akan menyebabkan harga saham mengalami kenaikan yang pada akhirnya akan berujung pada peningkatan return yang ditawarkan atas saham tersebut (Kusno, 2004). 
Nilai arus kas operasi yang semakin meningkat mengindikasikan kemampuan perusahaan yang semakin baik dalam memenuhi segala kewajibannya, baik itu kepada pemegang saham maupun kepada investor, sehingga membuat nilai perusahaan di mata investor akan semakin meningkat. Hal ini mengakibatkan semakin tinggi minat dari para investor untuk membeli saham perusahaan tersebut (Oktavia, 2008). Pada akhirnya hal ini membuat harga saham dari perusahaan tersebut meningkat. Dimana, peningkatan pada harga saham ini akan membuat return yang ditawarkan oleh saham tersebut meningkat pula (Kusno, 2004).

Nilai rasio PBV yang semakin besar menunjukkan bahwa semakin berhasil perusahaan dalam menciptakan nilai bagi para pemegang sahamnya (Hidayati, 2010). Hal ini akan membuat semakin tingginya penilaian dari investor terhadap perusahaan yang bersangkutan. Tingginya penilaian ini mengakibatkan semakin besarnya kemungkinan dari para investor tersebut untuk membeli saham dari perusahaan yang bersangkutan (Astuti, 2006). Sehingga harga saham dapat mengalami peningkatan dan pada akhirnya return saham dapat juga mengalami peningkatan.

Nilai EVA yang > 0 mengindikasikan bahwa perusahaan telah berhasil dalam menciptakan nilai bagi para pemilik modal. Kondisi yang terjadi apabila nilai EVA positif adalah timbulnya minat yang semakin tinggi dari para investor untuk mau menanamkan dananya ke dalam perusahaan tersebut dengan cara membeli saham yang dikeluarkan oleh perusahaan tersebut (Tinneke, 2007). Hal ini tentunya mendorong terjadinya permintaan yang semakin banyak terhadap saham dari perusahaan yang bersangkutan, sehingga harga saham cenderung meningkat di pasar modal (Tinneke, 2007). Peningkatan harga saham ini akan diiringi dengan peningkatan pada return saham yang ditawarkan oleh perusahaan yang bersangkutan (Astuti, 2006).

\section{Penelitian Terdahulu}

Dechow (1993) dalam penelitiannya yang berjudul "Accounting Earnings and Cash Flows As Measures Of Firm Performance The Role Of Accounting Accruals" menemukan bahwa Laba memiliki hubungan yang lebih tinggi dengan return saham daripada arus kas dalam perusahaan yang mengalami perubahan besar dalam modal kerja.

Ismail (2006) dalam penelitiannya yang berjudul "Is Economic Value Added More Associated With Stock Return Than Accounting Earnings?The UK Evidence" menemukan bahwa terdapat pengaruh secara simultan dari seluruh variabel bebas terhadap return saham dan variabel laba akuntansi yang diproksikan terhadap NI dan Nopat merupakan variabel yang paling dominan berpengaruh terhadap return saham.

Biddle et al. (1996) dalam penelitiannya yang berjudul "Does EVA Beat Earnings? Evidence On Associations With Stock Returns And Firm Values" menemukan bahwa terdapat pengaruh secara simultan dari seluruh variabel bebas terhadap return saham, laba merupakan variabel yang paling dominan berpengaruh terhadap return saham.

Martani, dkk (2009) dalam penelitiannya yang berjudul "The Effect Of Financial Ratios, Firm Size, And Cash Flow From Operating Activities In The 
Interim Report To The Stock Return" menemukan bahwa variabel NPM, ROE, PBV, dan Total Assets memiliki pengaruh positif yang signifikan dengan return saham, variabel CR dan TATO memiliki pengaruh yang negatif terhadap return saham, dan variabel DER dan Arus Kas Operasi memiliki pengaruh yang positif terhadap return saham, namun pengaruh tersebut tidak signifikan secara statistik.

Kusuma dan Rahardjo (2004) dalam penelitiannya yang berjudul "Kandungan Informasi Tambahan Dari Laba, Modal Kerja Operasi, Dan Arus Kas Pada Perusahaan Manufaktur Go Public Tahun 1997-2001" menemukan bahwa perubahan laba, perubahan modal kerja, dan perubahan arus kas operasi masingmasing memiliki kandungan informasi tambahan dalam memprediksi return saham.

Pradhono dan Christiawan (2004) dalam penelitiannya yang berjudul "Pengaruh Economic Value Added, Residual Income, Earnings, dan Arus Kas Operasi Terhadap Return Yang Diterima Oleh Pemegang Saham (Studi pada perusahaan manufaktur yang terdaftar di BEJ)" menemukan bahwa variabel EVA dan Residual Income masing-masing tidak mempunyai pengaruh yang signifikan terhadap return yang diterima oleh pemegang saham, variabel earnings dan arus kas operasi mempunyai pengaruh yang signifikan terhadap return yang diterima oleh pemegang saham, dan variabel arus kas operasi merupakan variabel yang berpengaruh paling dominan terhadap return saham.

\section{Hipotesis Penelitian}

Berdasarkan pada teori dan hasil penelitian terdahulu yang telah dijelaskan sebelumnya, maka dapat diajukan 4 hipotesis alternatif $\left(\mathrm{H}_{\mathrm{a}}\right)$ sebagai berikut:

H1: Laba Akuntansi (LAK) berpengaruh positif dan signifikan terhadap return saham.

H2: Arus Kas Operasi (AKO) berpengaruh positif dan signifikan terhadap return saham.

H3: Price to Book Value (PBV) berpengaruh positif dan signifikan terhadap return saham.

H4: Kinerja Keuangan Perusahaan dengan Pendekatan Economic Value Added (EVA) berpengaruh positif dan signifikan terhadap return saham.

\section{METODE PENELITIAN}

Penelitian ini merupakan salah satu penelitian yang termasuk ke dalam desain penelitian kausal. Disamping itu, metode penelitian yang digunakan dalam penelitian ini adalah metode penelitian kuantitatif. Jenis data yang dibutuhkan dalam penelitian ini berupa data kuantitatif dengan sumber sekunder. Adapun jenis-jenis data yang dibutuhkan dalam penelitian ini, diantaranya yaitu:

1. Laporan keuangan tahunan yang diaudit dari setiap perusahaan sampel selama kurun waktu 3 tahun dari tahun 2008-2010.

2. Data harga saham tahunan dan bulanan dari perusahaan sampel selama kurun waktu 3 tahun dari tahun 2008-2010.

3. Data pembagian dividen kas perusahaan sampel selama kurun waktu 3 tahun dari tahun 2008-2010.

4. Data bulanan tingkat suku bunga SBI selama tahun 2008-2010.

5. Data bulanan tingkat IHSG selama tahun 2008-2010. 
Untuk sumber data yang digunakan dalam penelitian ini diperoleh dari IDX Statistics, ICMD, laporan keuangan tahunan dari perusahaan sampel, situs resmi Bank Indonesia, dan beberapa literatur lainnya.

\section{Populasi dan Sampel Penelitian}

Penelitian ini menggunakan seluruh perusahaan pertambangan yang tercatat dan terdaftar di Bursa Efek Indonesia pada tahun 2008 sampai tahun 2010 sebagai populasi. Dari populasi ini kemudian diambil sampel dengan menggunakan teknik purposive sampling jenis judgment sampling untuk memperoleh sampel yang representatif atau mewakili populasi yang ada sesuai dengan kriteria yang telah dibuat. Berdasarkan teknik tersebut, hanya terdapat 20 perusahaan pertambangan yang dapat memenuhi semua kriteria yang telah ditetapkan.

\section{Variabel Penelitian}

Variabel yang digunakan dalam penelitian ini adalah sebagai berikut:

1. Variabel terikat (Y) adalah Return saham, merupakan tingkat keuntungan yang diperoleh pemegang saham atas investasi yang dimiliki dalam bentuk saham. Secara sistematis return saham dapat dirumuskan sebagai berikut:

$$
R_{i t}=\frac{P_{t}-P_{t-1}}{P_{t-1}}
$$

$\mathrm{R}_{\mathrm{it}}$ adalah return saham pada periode, $\mathrm{P}_{\mathrm{t}}$ adalah harga saham periode $\mathrm{t}$ (akhir periode), dan $\mathrm{P}_{\mathrm{t}-1}$ adalah harga saham pada periode $\mathrm{t}-1$ (awal periode).

2. Variabel bebas 1 (X1) adalah Laba Akuntansi, merupakan perbedaan antara revenue yang direalisasi yang timbul dari transaksi pada periode tertentu dihadapkan pada biaya-biaya yang dikeluarkan pada periode tersebut. Secara sistematis laba akuntansi dapat dirumuskan sebagai berikut:

$$
\text { LAK }=\frac{\text { NIAT }}{\text { Shares Outstanding }}
$$

3. Variable bebas 2 (X2) adalah Arus Kas operasi, merupakan arus kas yang berasal dari aktivitas penghasilan utama perusahaan dan aktivitas lain yang bukan berasal dari aktivitas investasi dan aktivitas pendanaan. Secara sistematis arus kas operasi dapat dirumuskan sebagai berikut:

$$
\text { AKO }=\frac{\text { Jumlah Arus Kas dari Aktivitas Operasi }}{\text { Shares Outstanding }}
$$

4. Variabel bebas 3 (X3) adalah Price to Book Value (PBV), merupakan salah satu rasio pasar yang digunakan untuk mengukur kinerja harga pasar saham terhadap nilai buku ekuitasnya. Secara sistematis PBV dapat dirumuskan sebagai berikut: 


$$
\mathrm{PBV}=\frac{\mathrm{Ps}}{\mathrm{BVs}}
$$

Ps adalah harga saham dan BVs adalah nilai buku.

5. Variable bebas 4 (X4) adalah Kinerja Keuangan Perusahaan dengan Pendekatan Economic Value Added (EVA), merupakan suatu pengukuran terhadap kinerja keuangan yang dimiliki suatu perusahaan yang dilakukan dengan memperhatikan dan memperhitungkan mengenai sejauh mana perusahaan mampu menciptakan nilai tambah bagi para pemilik modalnya. Secara sistematis EVA dapat dirumuskan sebagai berikut:

$$
\mathrm{EVA}=\mathrm{NOPAT}-(\text { WACC } \times \text { Capital })
$$

NOPAT adalah laba usaha setelah dikurangi pajak namun belum dikurangi biaya bunga, WACC adalah biaya rata-rata tertimbang, dan Capital adalah seluruh sumber pembiayaan yang digunakan oleh perusahaan untuk menghasilkan profit.

\section{Teknik Analisis Data}

Teknik analisis data yang digunakan dalam penelitian ini adalah teknik analisis regresi linier berganda dengan panel data (pooling data), yaitu gabungan antara data time series (antar waktu) dan data cross section (antar individu/ruang). Untuk dapat melakukan analisis regresi linier berganda, maka dalam penelitian ini digunakan alat analisa statistik, yang dinamakan dengan Statistical Product and Service Sollution (SPSS) versi 11.5.

Adapun tahap-tahap yang harus dilalui untuk dapat memperoleh hasil yang sesuai dengan tujuan dari penelitian ini adalah sebagai berikut:

1) Melakukan perhitungan atas setiap variabel yang akan dianalisis dalam penelitian ini;

2) Melakukan uji asumsi klasik, diantaranya adalah beberapa uji sebagai berikut: Uji Normalitas, Uji Multikolinieritas, Uji Heterokedastisitas, Uji Autokorelasi;

3) Mengukur nilai koefisien determinasinya $\left(\mathrm{R}^{2}\right)$;

4) Melakukan analisis regresi linier. Dalam penelitian ini digunakan model regresi linier berganda yang dapat dijelaskan secara sistematis sebagai berikut: $Y=\alpha+\beta_{1} X_{1}+\beta_{2} X_{2}+\beta_{3} X_{3}+\beta_{4} X_{4}+\varepsilon$;

5) Melakukan pengujian hipotesis. Pengujian hipotesis dalam penelitian ini dilakukan dengan menggunakan analisis regresi yang kemudian dilanjutkan dengan uji statistik t. 
HASIL DAN PEMBAHASAN

Return saham

Tabel 1. Hasil Perhitungan Return Saham

\begin{tabular}{cccc}
\hline Tahun & $\mathbf{2 0 0 8}$ & $\mathbf{2 0 0 9}$ & $\mathbf{2 0 1 0}$ \\
\hline Rata-rata & -0.4877 & 0.8653 & 0.2325 \\
\hline Max & 1.0349 & 2.3800 & 1.5667 \\
\hline Min & -0.9799 & -0.5643 & -0.5773 \\
\hline
\end{tabular}

Sumber: data diolah

Berdasarkan tabel 1 tersebut, terlihat bahwa nilai rata-rata return saham mengalami perubahan yang cukup berfluktuatif dengan nilai return saham tertinggi dicapai pada tahun 2009 yaitu sebesar 2.3800 dan nilai return saham terendah dicapai pada tahun 2008 yaitu sebesar -0.9799 .

Berdasarkan tabel 2 tersebut, terlihat bahwa nilai rata-rata laba akuntansi mengalami perubahan yang cukup berfluktuatif dengan nilai laba akuntansi tertinggi dicapai pada tahun 2010 yaitu sebesar 3,766.6452 dan nilai laba akuntansi terendah dicapai pada tahun 2010 yaitu sebesar -33.8396 .

\section{Laba Akuntansi}

Tabel 2. Hasil Perhitungan Laba Akuntansi

\begin{tabular}{cccc}
\hline Tahun & $\mathbf{2 0 0 8}$ & $\mathbf{2 0 0 9}$ & $\mathbf{2 0 1 0}$ \\
\hline Rata-rata & 297.4791 & 253.1061 & 402.6805 \\
\hline Max & $2,276.6367$ & $2,791.4945$ & $3,766.6452$ \\
\hline Min & -68.2671 & -120.3026 & -33.8396 \\
\hline
\end{tabular}

Sumber: data diolah

Arus Kas Operasi

Tabel 3. Hasil Perhitungan Arus Kas Operasi

\begin{tabular}{cccc}
\hline Tahun & $\mathbf{2 0 0 8}$ & $\mathbf{2 0 0 9}$ & $\mathbf{2 0 1 0}$ \\
\hline Rata-rata & 328.5928 & 488.0341 & 544.4956 \\
\hline Max & $2,285.7171$ & $3,566.5954$ & $5,657.4557$ \\
\hline Min & -26.4545 & -47.6808 & -36.0711 \\
\hline
\end{tabular}

Sumber: data diolah

Berdasarkan tabel 3 tersebut, terlihat bahwa nilai rata-rata arus kas operasi mengalami peningkatan yang cukup signifikan dengan nilai arus kas operasi tertinggi dicapai pada tahun 2010 yaitu sebesar 5,657.4557 dan nilai laba akuntansi terendah dicapai pada tahun 2009 yaitu sebesar -47.6808 . 
Price to Book Value (PBV)

Tabel 4. Hasil Perhitungan Price to Book Value

\begin{tabular}{cccc}
\hline Tahun & $\mathbf{2 0 0 8}$ & $\mathbf{2 0 0 9}$ & $\mathbf{2 0 1 0}$ \\
\hline Rata-rata & 2.5885 & 6.2964 & 15.9389 \\
\hline Max & 9.7925 & 59.5132 & 174.9042 \\
\hline Min & 0.3088 & 0.3885 & 0.4873
\end{tabular}

Sumber: data diolah

Berdasarkan tabel 4 tersebut, terlihat bahwa nilai rata-rata PBV mengalami peningkatan yang cukup signifikan dengan nilai PBV tertinggi dicapai pada tahun 2010 yaitu sebesar 174.9402 dan nilai laba akuntansi terendah dicapai pada tahun 2008 yaitu sebesar 0.3088 .

Berdasarkan tabel 5 tersebut, terlihat bahwa nilai rata-rata EVA mengalami perubahan yang cukup berfluktuatif dengan nilai EVA tertinggi dicapai pada tahun 2008 yaitu sebesar 9,719.8606 dan nilai EVA terendah dicapai pada tahun 2008 yaitu sebesar -990.1158 .

Kinerja Keuangan Perusahaan dengan Pendekatan Economic Value Added

Tabel 5. Hasil Perhitungan Economic Value Added

\begin{tabular}{cccc}
\hline Tahun & $\mathbf{2 0 0 8}$ & $\mathbf{2 0 0 9}$ & $\mathbf{2 0 1 0}$ \\
\hline Rata-rata & 727.0334 & 395.2051 & 533.5070 \\
\hline Max & $9,719.8606$ & $3,755.1313$ & $5,842.0814$ \\
\hline Min & -990.1158 & -141.4526 & -109.8130 \\
\hline
\end{tabular}

Sumber: data diolah

\section{Hasil Pengujian Asumsi Klasik}

\section{Uji Normalitas}

Dalam penelitian ini, pengujian normalitas dilakukan dengan melakukan uji grafik histogram, normal probability plot, dan uji Kolomogorov-Smirnov (KS). Berikut ini hasil dari ketiga uji tersebut: 
Histogram

Dependent Variable: RETURN

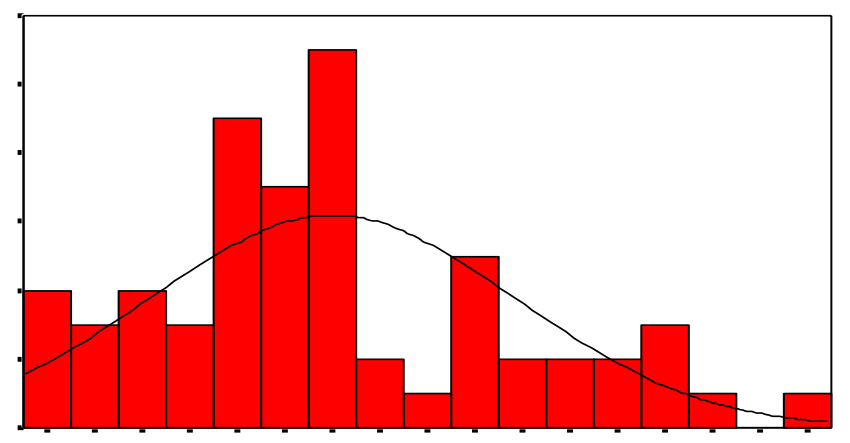

Regression Standardized Residual

Sumber: Output SPSS 11.5; diolah

\section{Gambar 1. Hasil Uji Grafik Histogram}

Berdasarkan gambar 1 di atas, terlihat bahwa gambar grafik histogram telah menunjukkan pola distribusi histogram yang mengikuti distribusi normal dengan berbentuk seperti bel.

\section{Uji Multikolinieritas}

Dalam penelitian ini, pengujian multikolinieritas dilakukan dengan cara melihat nilai tolerance, Variance Inflation Factor, dan condition index. Berikut ini hasil uji dari ketiga cara tersebut:

Tabel 6. Hasil Uji Tolerance dan VIF

\begin{tabular}{|c|c|c|c|}
\hline \multirow{2}{*}{\multicolumn{2}{|c|}{ Model }} & \multicolumn{2}{|c|}{ Collinearity Statistics } \\
\hline & & Tolerance & VIF \\
\hline \multirow[t]{5}{*}{1} & (Constant) & & \\
\hline & LAK & .414 & 2.416 \\
\hline & $\mathrm{AKO}$ & .404 & 2.473 \\
\hline & PBV & .834 & 1.199 \\
\hline & EVA & .516 & 1.937 \\
\hline
\end{tabular}

Sumber: Output SPSS 11.5; diolah

\section{Uji Heterokedastisitas}

Dalam penelitian ini, pengujian heterokedastisitas dilakukan dengan cara melihat grafik scatterplot dan uji Spearman' Rank Correlation. Berikut ini hasil uji dari kedua cara tersebut: 
Scatterplot

Dependent Variable: RETURN

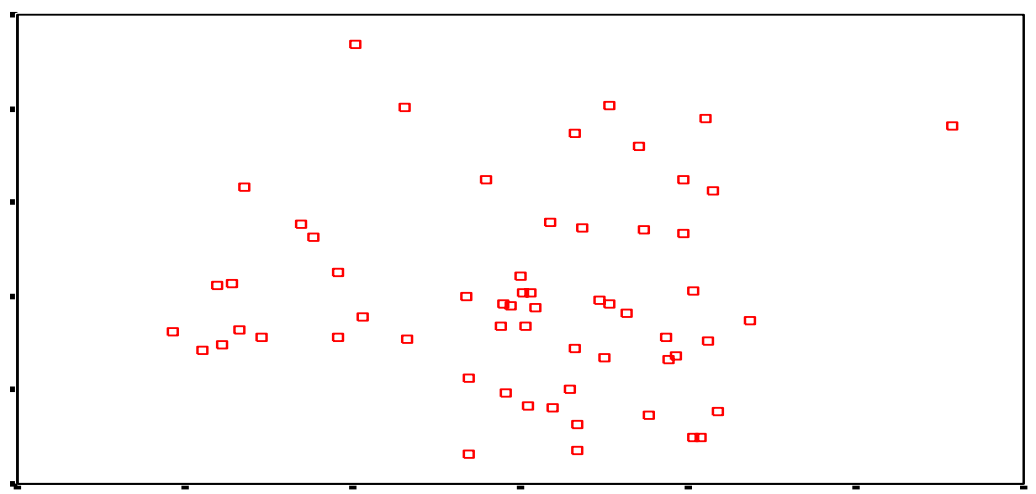

Regression Standardized Predicted Value

Sumber: Output SPSS 11.5; diolah

\section{Gambar 3. Hasil Uji Grafik Scatterplot}

Berdasarkan gambar 3 di atas, terlihat bahwa titik-titik yang ada tidak membentuk pola tertentu yang teratur, sehingga dapat dikatakan tidak terdapat gejala heterokedastisitas. Adapun hasil uji Spearman's Rank Correlation adalah sebagai berikut: 
Tabel 7. Hasil Uji Spearman's Rank Correlation

\begin{tabular}{lllr}
\hline & & & Unstandardized Residual \\
\hline $\begin{array}{l}\text { Spearman's } \\
\text { rho }\end{array}$ & LAK & Sig. (2-tailed) & .573 \\
\cline { 2 - 4 } & AKO & Sig. (2-tailed) & .883 \\
\cline { 2 - 4 } & PBV & Sig. (2-tailed) & .874 \\
\cline { 2 - 4 } & EVA & Sig. (2-tailed) & .656 \\
\hline
\end{tabular}

* Correlation is significant at the 0.05 level (2-tailed).

Sumber: Output SPSS 11.5; diolah

Berdasarkan data tabel 9 tersebut, terlihat bahwa nilai signifikansi yang terbentuk dari keempat variabel bebas jauh lebih besar dari taraf signifikansi sebesar 0,05. Dengan demikian dapat disimpulkan bahwa tidak terdapat gejala heterokedastisitas.

\section{Uji Autokorelasi}

Dalam penelitian ini, pengujian autokorelasi dilakukan dengan cara melakukan uji grafik. Berdasarkan gambar 4, terlihat bahwa grafik telah membentuk plot yang acak baik di atas maupun di bawah angka nol pada sumbu Y. Sehingga, dapat disimpulkan bahwa tidak terdapat gejala autokorelasi pada model regresi.

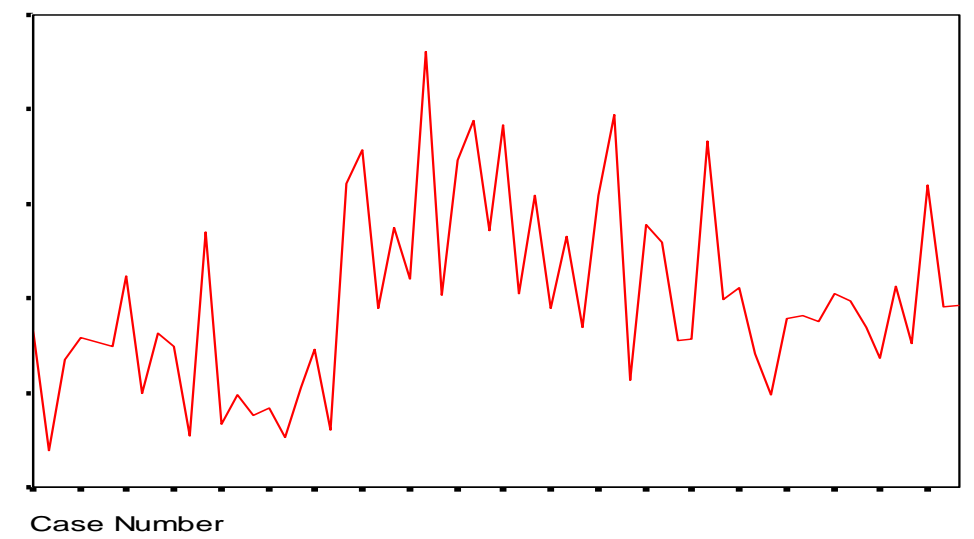

Sumber: Output SPSS 11.5; diolah

\section{Gambar 4. Hasil Uji Metode Grafik}

Sedangkan hasil perhitungan uji koefisien determinasi $\left(\mathrm{R}^{2}\right)$ pada model regresi dalam penelitian ini:

Tabel 8. Hasil Perhitungan Uji Koefisien Determinasi $\left(\mathbf{R}^{2}\right)$

\begin{tabular}{lrrr}
\hline & Model & R & \multicolumn{1}{c}{ R Square } \\
\hline 1 & & $.511(\mathrm{a})$ & .261 \\
\hline
\end{tabular}

Sumber: Output SPSS 11.5; diolah 
Berdasarkan data tabel 8 tersebut, terlihat bahwa nilai koefisien determinasi yang dapat diterangkan oleh model regresi dalam penelitian ini adalah sebesar 26,1\%.

\section{Hasil Analisis Regresi Linear Berganda}

Berikut ini hasil analisis regresi dari masing-masing variabel independen terhadap variabel dependen:

\section{Tabel 9. Hasil Analisis Regresi Linear Berganda}

\begin{tabular}{llc}
\hline & & \multicolumn{2}{c}{ Unstandardized Coefficients } \\
\cline { 3 - 3 } Model & & \multicolumn{2}{c}{ B } \\
\hline 1 & (Constant) & .000 \\
& LAK & .065 \\
& AKO & -.108 \\
& PBV & .348 \\
& EVA & .174 \\
\hline
\end{tabular}

Dependent Variable: RETURN

Sumber: Output SPSS 11.5; diolah

Berdasarkan data tabel 11 di atas, diperoleh persamaan regresi linear berganda sebagai berikut: $\mathrm{Y}=0,000+0,065 \mathrm{X}_{1}-0,108 \mathrm{X}_{2}+0,348 \mathrm{X}_{3}+0,174 \mathrm{X}_{4}$, artinya: konstanta sebesar 0,000 menyatakan bahwa jika variabel bebas dianggap konstan (nol), maka besarnya nilai return saham akan sebesar 0, nilai koefisien regresi LAK sebesar 0,065 menunjukkan bahwa variabel laba akuntansi memiliki pengaruh positif terhadap return saham, nilai koefisien regresi AKO sebesar -0,108 menunjukkan bahwa variabel arus kas operasi memiliki pengaruh negatif terhadap return saham, nilai koefisien regresi PBV sebesar 0,348 menunjukkan bahwa variabel Price to Book Value memiliki pengaruh positif terhadap return saham, dan nilai koefisien regresi EVA sebesar 0,174 menunjukkan bahwa variabel Kinerja Keuangan Perusahaan dengan Pendekatan EVA memiliki pengaruh positif terhadap return saham

\section{Hasil Pengujian Hipotesis (Uji t)}

Berikut ini hasil perhitungan uji t melalui program SPSS versi 11.5:

Tabel 10. Hasil Perhitungan Uji t

\begin{tabular}{|c|c|c|c|c|}
\hline \multicolumn{5}{|c|}{ Unstandardized } \\
\hline \multicolumn{2}{|c|}{ Model } & $\mathrm{B}$ & & \\
\hline \multirow[t]{5}{*}{1} & (Constant) & .000 & -.001 & .999 \\
\hline & LAK & .065 & .660 & .512 \\
\hline & $\mathrm{AKO}$ & -.108 & -.993 & .325 \\
\hline & EVA & .174 & 2.572 & .013 \\
\hline & PBV & .348 & 1.853 & .069 \\
\hline
\end{tabular}

Sumber: Output SPSS 11.5; diolah 
Berdasarkan data tabel 10 tersebut, terlihat bahwa terdapat dua variabel independen yaitu Price to Book Value (PBV) dan Kinerja Keuangan Perusahaan dengan Pendekatan (EVA) yang memiliki pengaruh signifikan terhadap return saham. Sedangkan, variabel Laba Akuntansi dan Arus Kas Operasi tidak memiliki pengaruh terhadap return saham.

\section{PEMBAHASAN}

\section{Pengaruh Laba Akuntansi Terhadap Return Saham}

Berdasarkan hasil penelitian yang telah dilakukan, dapat diketahui bahwa secara statistik tidak terdapat pengaruh antara variabel laba akuntansi terhadap return saham. Hasil yang tidak berpengaruh ini menunjukkan bahwa para investor belum secara sungguh-sungguh dan konsisten mempergunakan informasi laba akuntansi dari suatu perusahaan dalam memprediksi return saham dari suatu investasi. Adapun penyebab dari ketidaksignifikanan dalam hasil ini adalah karena adanya fluktuasi yang cukup signifikan pada data laba akuntansi yang diperoleh. Dimana, nilai standar deviasi dari variabel laba akuntansi sebesar 1,5110719 lebih besar dari nilai rata-rata (mean) yang sebesar 1,381075.

Hasil penelitian ini telah didukung oleh hasil penelitian lain yang telah dilakukan oleh Kusno (2004), dimana dalam penelitian tersebut ditemukan bahwa variabel laba akuntansi tidak memiliki pengaruh terhadap return saham. Ketidaksignifikanan hasil pada penelitian tersebut disebabkan karena perusahaan keuangan yang menjadi sampel mengalami penurunan dalam jumlah laba akuntansi yang diperoleh.

\section{Pengaruh Arus Kas Operasi Terhadap Return Saham}

Berdasarkan hasil penelitian yang telah dilakukan, dapat diketahui bahwa secara statistik tidak terdapat pengaruh antara variabel arus kas operasi terhadap return saham. Hasil ini menunjukkan bahwa para investor tidak secara sungguh-sungguh dan konsisten mempergunakan informasi arus kas operasi dari suatu perusahaan dalam memprediksi return saham dari suatu investasi. Adapun penyebab dari ketidaksignifikanan dalam hasil ini adalah karena adanya beberapa perusahaan sampel yang mengalami defisit dalam jumlah arus kas operasi yang diperoleh atau memperoleh arus kas operasi yang bernilai negatif. Perusahaan yang memiliki nilai arus kas operasi yang bernilai negatif, tidak lagi memiliki kemampuan untuk menghasilkan arus kas operasi yang cukup memadai guna melunasi pinjaman, memelihara kemampuan operasi perusahaan, membayar dividen, dan melakukan investasi baru.

Hasil penelitian ini telah didukung oleh hasil penelitian lain yang dilakukan oleh Sjuchur (2001), dimana dalam penelitian tersebut ditemukan bahwa perubahan arus kas operasi tidak memiliki pengaruh terhadap return saham. Tidak adanya pengaruh diantara kedua variabel pada penelitian tersebut disebabkan oleh adanya sikap kecenderungan dari para investor untuk tidak memperhatikan perubahan pada komponen arus kas operasi dalam melakukan investasi saham di BEJ.

\section{Pengaruh Price to Book Value (PBV) Terhadap Return Saham}

Berdasarkan hasil penelitian yang telah dilakukan, dapat diketahui bahwa secara statistik terdapat pengaruh yang positif dan signifikan antara variabel Price to Book Value (PBV) terhadap return saham. Hasil ini menunjukkan bahwa informasi mengenai nilai rasio PBV dari suatu perusahaan sangat menjadi fokus perhatian dan menjadi faktor pertimbangan yang selalu digunakan oleh para investor sebelum memutuskan tindakan investasinya. 
Dijadikannya informasi rasio PBV sebagai faktor pertimbangan yang sangat menentukan keputusan investasi yang akan diambil oleh seorang investor, karena nilai PBV ini merupakan indikator yang sangat sesuai untuk digunakan dalam menilai kinerja suatu perusahaan. Dalam hal ini, tinggi rendahnya nilai rasio PBV ini mencerminkan kondisi kinerja keuangan suatu perusahaan. Disamping itu, nilai rasio PBV juga dapat digunakan oleh para investor untuk menentukan strategi investasi yang paling tepat. Dalam hal ini, besar kecilnya nilai rasio PBV dapat menunjukkan tinggi rendahnya harga pasar dari suatu saham terhadap nilai bukunya.

Hasil penelitian ini didukung oleh hasil penelitian lain yang dilakukan Astuti (2006), dimana dalam penelitian tersebut ditemukan bahwa PBV memiliki pengaruh yang signifikan terhadap return saham. Hasil yang signifikan dalam penelitian tersebut mengindikasikan bahwa nilai PBV yang semakin besar menunjukkan bahwa harga pasar dari saham tersebut semakin meningkat.

\section{Pengaruh Kinerja Keuangan Perusahaan dengan Pendekatan Economic Value Added (EVA) Terhadap Return Saham}

Berdasarkan hasil penelitian yang telah dilakukan, dapat diketahui bahwa secara statistik terdapat pengaruh yang signifikan antara variabel Kinerja Keuangan Perusahaan dengan Pendekatan EVA terhadap return saham. Hasil ini menunjukkan bahwa informasi mengenai EVA dari suatu perusahaan sangat menjadi fokus perhatian dan menjadi faktor pertimbangan yang selalu digunakan oleh para investor sebelum memutuskan tindakan investasinya.

Dijadikannya EVA sebagai faktor pertimbangan yang sangat menentukan keputusan investasi yang akan diambil oleh seorang investor karena EVA merupakan ukuran kinerja yang paling baik untuk dapat menjelaskan economic profit dari suatu perusahaan dibandingkan dengan ukuran kinerja lainnya. Disamping itu, informasi mengenai EVA sangat berhubungan langsung dengan kondisi intrinsik suatu perusahaan. Sebab, di dalam EVA akan diukur nilai tambah dengan cara mengurangi biaya modal yang timbul akibat investasi yang dilakukan oleh perusahaan.

Hasil penelitian ini telah konsisten dengan hasil penelitian lain yang dilakukan oleh Christanty (2009), dimana dalam penelitian tersebut ditemukan bahwa variabel EVA memiliki pengaruh yang signifikan terhadap return saham. Hasil pengujian yang signifikan tersebut mencerminkan bahwa perusahaan mampu menciptakan nilai tambah bagi pemilik modalnya.

\section{SIMPULAN DAN SARAN Simpulan}

Laba Akuntansi tidak memiliki pengaruh terhadap return saham. Hasil ini telah menunjukkan bahwa perusahaan yang memiliki nilai laba akuntansi yang bernilai negatif, tidak lagi memiliki kemampuan untuk menghasilkan laba yang memadai dan membagikan deviden kepada para pemegang sahamnya.

Arus Kas Operasi tidak memiliki pengaruh terhadap return saham. Hasil penelitian ini telah menunjukkan bahwa perusahaan yang memiliki nilai arus kas operasi yang bernilai negatif, tidak lagi memiliki kemampuan untuk menghasilkan arus kas operasi yang cukup memadai guna melunasi pinjaman, memelihara kemampuan operasi perusahaan, membayar dividen, dan melakukan investasi baru.

Price to Book Value (PBV) memiliki pengaruh positif dan signifikan terhadap return saham. Hasil ini menunjukkan bahwa para investor sangat berfokus untuk memperhatikan informasi mengenai nilai rasio PBV dalam pengambilan keputusan investasinya. 
Kinerja Keuangan Perusahaan dengan Pendekatan Economic Value Added (EVA) memiliki pengaruh positif dan signifikan terhadap return saham. Hasil ini menunjukkan bahwa para investor sangat berfokus untuk memperhatikan informasi mengenai nilai EVA dalam pengambilan keputusan investasinya.

\section{Saran}

1. Bagi para investor khususnya yang ingin berinvestasi dalam instrumen saham, sebaiknya perlu memperhatikan informasi mengenai nilai rasio PBV dan nilai EVA. Sebab, dalam penelitian ini telah dibuktikan bahwa kedua variabel tersebut merupakan acuan yang paling tepat untuk dapat digunakan oleh investor dalam menentukan strategi investasinya

2. Bagi para peneliti lain, disarankan untuk menambahkan variabel lain yang turut mempengaruhi return saham, seperti variabel ekonomi makro, faktor fundamental lain, ukuran perusahaan, dan lain-lain. Disamping itu, dalam penelitian yang selanjutnya diharapkan dapat menggunakan data dengan periode rentang waktu penelitian yang lebih panjang dan dapat menggunakan sampel perusahaan yang lebih banyak. 


\section{DAFTAR PUSTAKA}

Anoraga, Pandji dan Piji, Pakarti. 2008. Pengantar Pasar Modal. Jakarta: Rineka Cipta

Astuti, Subekti Puji. 2006. Analisis Pengaruh Faktor-Faktor Fundamental, EVA, Dan MVA Terhadap Return Saham. Tesis. Semarang: Magister Manajemen Universitas Diponegoro.

Biddle, Gary C. dkk. 1997. Does EVA Beat Earnings? Evidence On Associations With Stock Returns And Firm Values. Journal Of Accounting And Economics, 24, p. 301 - 336.

Bramantyo, Roy. 2006. Pengaruh Debt To Equity Ratio (DER), Price To Book Value (PBV), Dan Dividend Payout Ratio (DPR) Terhadap Return Saham Pada Perusahaan Manufaktur. Tesis. Semarang: Magister Manajemen Universitas Negeri Semarang.

Christanty, Mila. 2009. Analisis Pengaruh Faktor Fundamental Dan Economic Value Added (EVA) Terhadap Return Saham. Tesis. Semarang: Magister Manajemen Universitas Diponegoro.

Dechow, Patricia M. 1994. Accounting Earnings And Cash Flows As Measures Of Firm Performance The Role Of Accounting Accruals. Journal Of Accounting and Economics, p. $3-42$.

Faried, Asbi Rachman. 2008. Analisis Pengaruh Faktor Fundamental dan Nilai Kapitalisasi Pasar Terhadap Return Saham Perusahaan Manufaktur Di BEI Periode 2002 s.d 2006. Tesis. Semarang: Magister Manajemen Universitas Diponegoro.

Ghozali, Imam. 2001. Aplikasi Analisis Multivariate Dengan Program SPSS. Semarang: Badan Penerbit UNDIP

Halim, Abdul. 2005. Analisis Investasi. Jakarta: Salemba Empat.

Harahap, Sofyan Syafri. 2007. Teori Akuntansi. Edisi Revisi. Jakarta: PT. RajaGrafindo Persada.

Hidayati, Eva Eko. 2010. Analisis Pengaruh DER, DPR, ROE, Dan Size Terhadap PBV Perusahaan Manufaktur Yang Listing Di BEI Periode 2005-2007. Tesis. Semarang: Magister Manajemen Universitas Diponegoro.

Ikatan Akuntansi Indonesia. 2004. Standar Akuntansi Keuangan Per 1 Juni 2004. Buku Satu. Jakarta: Salemba Empat.

Ismail, Ahmad. 2006. Is Economic Value Added More Associated With Stock Return Than Acoounting Earnings? The UK Evidence. International Journal Of Managerial Finance, Vol. 2, No. 4, p. 343-353.

Kusno, Joko. 2004. Analisis Pengaruh Perubahan Arus Kas Dan Laba Akuntansi Terhadap Return Saham. Tesis. Semarang: Magister Manajemen Universitas Diponegoro.

Kusuma, Hadri dan Handojo, Budi Rahardjo. 2004. Kandungan Informasi Tambahan Dari Laba, Modal Kerja Operasi Dan Arus Kas Pada Perusahaan Manufaktur Go Public Tahun 1997-2001. Jurnal Bisnis Dan Manajemen, Vol. 7, No.1, Hal 1 - 12.

Martani, Dwi, dkk. 2009. The Effect Of Financial Ratios, Firm Size, And Cash Flow From Operating Activities In The Interim Report To The Stock Return. Journal of Business, Vol. 8, No. 6, Serial No. 72.

Munawir, S. 2002. Akuntansi Keuangan \& Manajemen. Yogyakarta: BPFE Yogyakarta.

Oktavia, Vicky. 2008. Analisis Pengaruh Total Arus Kas, Komponen Arus Kas, Dan Laba Akuntansi Terhadap Harga Saham Di Bursa Efek Jakarta. Tesis. Semarang: Magister Manajemen Universitas Diponegoro. 
Pradhono dan Yulius, Jogi Christiawan. 2004. Pengaruh Economic Value Added, Residual Income, Earnings, Dan Arus Kas Operasi Terhadap Return Yang Diterima Oleh Pemegang Saham. Jurnal Akuntansi \& Keuangan, Vol. 6, No. 2, Hal: 140-166

Sjuchur, Moch Abdul. 2001. Analisis Pengaruh Laba Akuntansi Dan Arus Kas Serta Perubahannya Terhadap Harga Dan Return Saham Dengan Menggunakan Model Levels Dan Model Return. Tesis. Semarang: Magister Manajemen Universitas Diponegoro.

Sunardi, Harjono. 2010. Pengaruh Penilaian Kinerja Dengan ROI dan EVA Terhadap Return Saham Pada Perusahaan Yang Tergabung Dalam Indeks LQ 45 Di Bursa Efek Indonesia. Jurnal Akuntansi, Vol. 2, No. 1, Hal 70-92.

Tandelilin, Eduardus. 2001. Analisis Investasi dan Manajemen Portofolio. Yogyakarta: BPFE

Tinneke, Raden. 2007. Analisis Pengaruh economic value added (EVA) dan faktor-faktor fundamental perusahaan lainnya terhadap return saham. Tesis. Semarang: Magister Manajemen Universitas Diponegoro.

Wild, John J. dkk. 2005. Analisis Laporan Keuangan. Edisi 8, Buku Satu. Jakarta: Salemba Empat. 